\title{
Posterior Juxtascleral Route of Administration
}

National Cancer Institute

\section{Source}

National Cancer Institute. Posterior Juxtascleral Route of Administration. NCI Thesaurus.

Code C149764.

Administration of a medicinal product beneath the sub-tenon membrane of the sclera

(i.e. in the episcleral space), adjacent to the macula. 